\title{
Cardiac tamponade as an initial manifestation of systemic lupus erythematosus
}

\author{
Diego M Carrion, ${ }^{1}$ Andres F Carrion ${ }^{2}$ \\ ${ }^{1}$ Universidad de Cuenca, Cuenca, Azuay, Ecuador \\ ${ }^{2}$ Department of Medicine, University of Miami Miller School of Medicine, Miami, Florida, USA \\ Correspondence to Diego M Carrion, diegocarrionm@hotmail.com
}

\section{Summary}

Clinical manifestations of pericardial disease may precede other signs and symptoms associated with systemic lupus erythematosus. Although pericardial effusion is one of the most common cardiac problems in patients with systemic lupus erythematosus, haemodynamically significant effusions manifesting as cardiac tamponade are rare and require prompt diagnosis and treatment.

\section{BACKGROUND}

Cardiac tamponade is a rare complication of systemic lupus erythematosus (SLE) and in a very small number of patients it can be the initial manifestation of the disease. ${ }^{12}$ We report a case of subacute cardiac tamponade heralding the diagnosis of SLE in an otherwise healthy young man. This case highlights the importance of considering connective tissue diseases in the differential diagnosis of pericardial effusions and cardiac tamponade.

\section{CASE PRESENTATION}

A 19-year-old black man without a significant medical history was admitted to the hospital with a 1-month history of fever, night sweats, malaise, dry cough, dyspnoea and intermittent substernal chest pain. The pain occurred at rest and during exertion; it was sharp in quality and exacerbated with the supine position and partially relieved by sitting up and leaning forward. The patient denied recent infections, sick contacts, travel and trauma to the chest. Review of systems was relevant for absence of recent weight changes, lymphadenopathy, headache, mucocutaneous ulcerations, arthralgias, myalgias, nausea, vomiting, diarrhoea, constipation, wheezing, sputum production, orthopnoea, paroxysmal nocturnal dyspnoea, oedema, dysuria, haematuria and sensory or motor neurological deficits. His mother had hypothyroidism and his father had hypertension; no family members had a history of cardiovascular disease, connective tissue disorders or malignant neoplasms. Physical examination revealed normal blood pressure, respiratory rate and peripheral oxygen saturation on ambient air. Jugular venous pressure was elevated at $9 \mathrm{~cm}$, and pulsus paradoxus was noted with a $20 \mathrm{~mm} \mathrm{Hg}$ drop in systolic blood pressure during inspiration (from 128 to $108 \mathrm{~mm} \mathrm{Hg}$ ), tachycardia (145 beats per minute), muffled heart sounds and mucocutaneous pallor. No skin rashes or mucosal ulcerations in the oral cavity were noted. Otherwise, the rest of the physical examination was unremarkable.

\section{INVESTIGATIONS}

Biomarkers for acute ischaemic heart disease were negative and an ECG showed sinus tachycardia, ST-segment elevations in the lateral and inferior leads, PR-segment depression and electrical alternans (figure 1). An anteroposterior chest radiograph revealed massive enlargement of the cardiac silhouette (figure 2). A large pericardial effusion with signs of diastolic collapse of the right chambers was identified with a transthoracic echocardiogram (figure 3). The patient underwent emergent pericardiocentesis and 1.6 litres of serosanguineous fluid were removed. Analysis of the pericardial fluid revealed 52654 erythrocytes $/ \mathrm{mm}^{3}$, 1849 leucocytes $/ \mathrm{mm}^{3}$ (79\% neutrophils), glucose $77 \mathrm{mg} / \mathrm{dl}$ (serum glucose $92 \mathrm{mg} / \mathrm{dl}$ ) and total protein $4.1 \mathrm{~g} / \mathrm{dl}$ (serum total protein $7.2 \mathrm{~g} / \mathrm{dl}$ ). Many erythrocytes, acute and chronic inflammatory cells and some reactive mesothelial cells were seen on cytological examination of the fluid. No malignant cells were noted. Gram stain and culture of the pericardial fluid were negative for micro-organisms. Polymerase chain reaction assay for Mycobacterium tuberculosis in the pericardial fluid was negative. Further diagnostic workup revealed positive serum antinuclear antibodies in a homogenous pattern (1:160 serum dilution), positive anti-double stranded deoxyribonucleic acid antibodies and

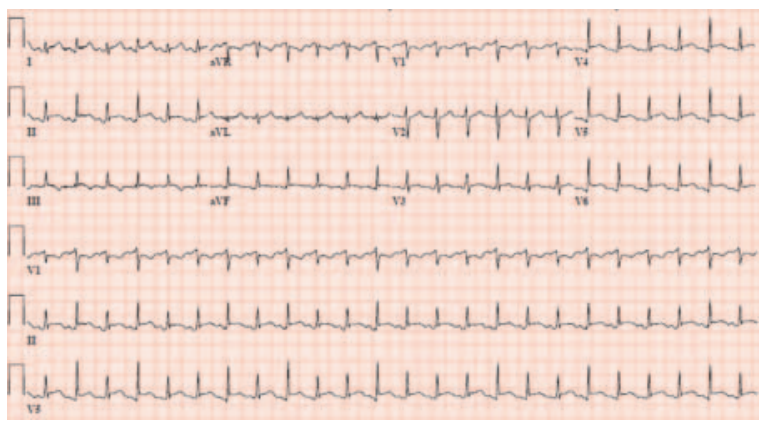

Figure 1 ECG revealing sinus tachycardia, PR-segment depression, electrical alternans and mild ST-segment elevations in the inferior and anterolateral leads. 


\section{BMJ Case Reports}

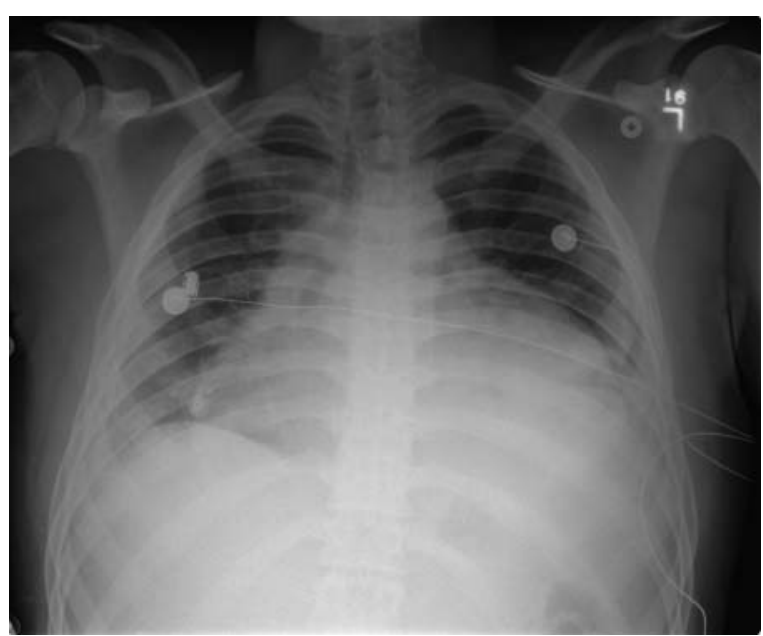

Figure 2 Anteroposterior chest radiograph showing massive enlargement of the cardiac silhouette.

low C3 and C4 complement levels. Serological test for human immunodeficiency virus was negative. Serum level of thyroid-stimulating hormone was normal. Serum creatinine and blood urea nitrogen were normal. Urinalysis did not reveal proteinuria or glycosuria; microscopic analysis of the urine sediment showed four leucocytes and no erythrocytes per high-power field.

\section{DIFFERENTIAL DIAGNOSIS}

Differential diagnosis of pericardial effusion in a young, healthy man without history of trauma includes ${ }^{3}$ :

- Infections (bacterial, mycobacterial, viral, fungal, parasitic)

- Neoplasms

- Connective tissue diseases

- Uremia

- Hypothyroidism

- Vasculitis

- Idiopathic

\section{TREATMENT}

The patient was initially treated for SLE with highdose systemic glucocorticoids. Hydroxychloroquine was subsequently started and the dose of glucocorticoids was gradually tapered.

\section{OUTCOME AND FOLLOW-UP}

The patient had excellent clinical response and echocardiographic follow-up demonstrated complete resolution of the pericardial effusion without recurrence. No clinical symptoms related to SLE or pericardial disease were reported at 6 and 12 months of follow-up.

\section{DISCUSSION}

Cardiac manifestations of SLE include pericarditis, myocarditis, endocarditis and conduction system abnormalities. ${ }^{4}$ Pericardial effusion is the most common cardiac manifestation of SLE, occurring in up to $50 \%$ of patients somewhere in the course of the disease. ${ }^{45}$ This complication is usually mild, infrequently observed early in the disease course and rarely leads to cardiac tamponade. ${ }^{6-8}$ Nevertheless, in a small number of cases, pericardial effusions may accumulate slowly without causing symptoms until cardiac tamponade develops. Although cardiac tamponade is seldom seen in children, adolescents and young adults, it can occasionally be the initial manifestation of SLE and after emergent treatment for cardiac tamponade is instituted, workup for SLE should be pursued if the underlying cause is not readily explained by another disease process.

Pericardial involvement (pericarditis and pericardial effusion) is also relatively common in other connective tissue diseases such as systemic sclerosis ( $>60 \%$ ), rheumatoid arthritis $(10-30 \%)$, mixed connective tissue disease (10-30\%), Sjögren's syndrome $(<30 \%)$, adult Still's disease $(<30 \%)$, polymyositis and dermatomyositis $(<10 \%) .{ }^{10-14}$ Clinically evident pericarditis occurs rarely in sarcoidosis; nevertheless, small and usually silent pericardial effusions may be detected by echocardiography. ${ }^{15}$

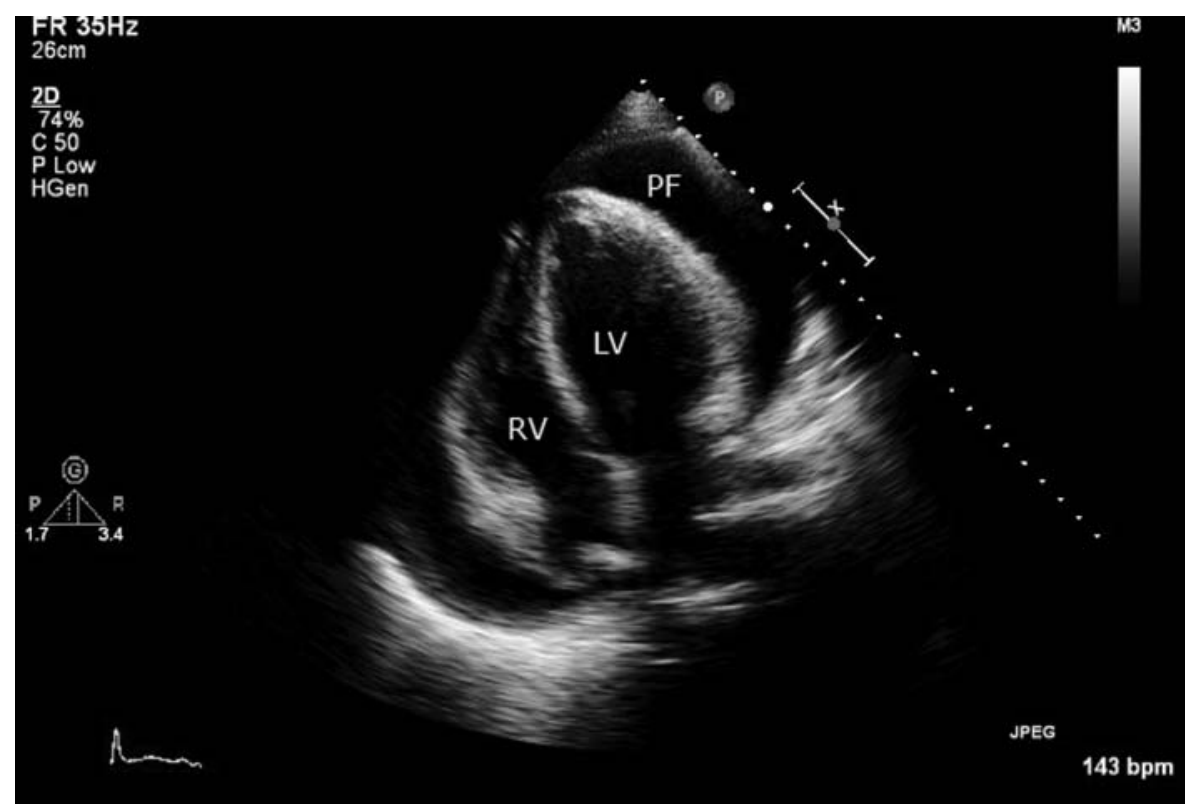

Figure 3 Echocardiogram demonstrating a large pericardial effusion and right ventricular collapse during the end of diastole. RV, right ventricle; $L V$, left ventricle; PF, pericardial fluid. 
Cardiac tamponade is a medical emergency for which early diagnosis and treatment are critical in reducing morbidity and mortality. Among the clinical signs suggestive of cardiac tamponade, the presence of pulsus paradoxus (>12 $\mathrm{mm} \mathrm{Hg}$ ) has positive and negative likelihood ratios of 5.9 and 0.03 , respectively. ${ }^{16}$ Other important clinical findings with high sensitivity for diagnosing cardiac tamponade but with low specificity are dyspnoea, cardiomegaly on chest radiograph, tachycardia and elevated jugular venous pressure. ${ }^{16}$ Pericardiocentesis is the treatment of choice for cardiac tamponade; nevertheless, high-dose corticosteroids appear to have an adjuvant role in reducing the frequency of repeated pericardiocentesis, use of pericardial drains and the need for a pericardial window when SLE is the underlying aetiology. 17

The characteristics of the pericardial fluid can lead to the correct diagnosis of connective tissue disease, and particularly SLE, only when the appropriate tests are ordered. The fluid is typically described as haemorrhagic in appearance, and although we did not test for antinuclear antibodies, complement levels or presence of immune complexes in the pericardial fluid, these markers can be useful in establishing the diagnosis. Protein concentration in the pericardial fluid can vary (being low in transudates and elevated in exudates) but glucose levels are typically within normal limits in cases of SLE pericardial effusion. ${ }^{18}$

\section{Learning points}

- Systemic lupus erythematosus (SLE) and other connective tissue diseases (ie, systemic sclerosis, rheumatoid arthritis, mixed connective tissue disease) are well-recognised causes of pericardial effusion, and less commonly of cardiac tamponade.

- Cardiac tamponade may be the initial manifestation of connective tissue diseases such as SLE.

- Pericardiocentesis and pericardial fluid analysis along with specific serological testing are important in diagnosing the aetiology of pericardial effusions.

\section{Competing interests None.}

Patient consent Obtained. This patient was not involved in a clinical trial.

\section{REFERENCES}

1. Doria A, laccarino L, Sarzi-Puttini $P$, et al. Cardiac involvement in systemic lupus erythematosus. Lupus 2005:14:683-6.

2. Reiner JS, Furie RA. Cardiac tamponade as an initial manifestation of systemic lupus erythematosus. J Rheumatol 1989;16:1127-9.

3. Corey GR, Campbell PT, VanTrigt $\mathrm{P}$, et al. Etiology of large pericardial effusion. Am J Med 1993;95:209-13.

4. Cauduro SA, Moder KG, Tsang TS, et al. Clinical and echocardiographic characteristics of hemodynamically significant pericardial effusions in patients with systemic lupus erythematosus. Am J Cardiol 2003;92:1370-2.

5. Swinkels BM, Scheffer RC, Tahapary GJ, et al. Cardiac tamponade as the initial manifestation of systemic lupus erythematosus in a young female patient. Neth Heart J 2007;15:71.

6. Knockaert DC. Cardiac involvement in systemic inflammatory diseases. Eur Heart J 2007;28:1797-804.

7. Gulati S, Kumar L. Cardiac tamponade as an initial manifestation of systemic lupus erythematosus in early childhood. Ann Rheum Dis 1992:51:279-80.

8. Muñiz AE. Pericardial tamponade presenting as abdominal pain in a patient with systemic lupus erythematosus. CJEM 2000;2:117-20.

9. Ameli S, Shah PK. Cardiac tamponade. Pathophysiology, diagnosis, and management. Cardiol Clin 1991;9:665-74.

10. Byers RJ, Marshall DA, Freemont AJ. Pericardial involvement in systemic sclerosis. Ann Rheum Dis 1997;56:393-4.

11. Voskuyl AE. The heart and cardiovascular manifestations of rheumatoid arthritis. Rheumatology (Oxford) 2006;45(Suppl 4):iv4-7.

12. Lundberg IE. Cardiac involvement in autoimmune myositis and mixed connective tissue disease. Lupus 2005;14:708-12.

13. Gyöngyösi M, Pokorny G, Jambrik Z, et al. Cardiac manifestations in primary Sjögren's syndrome. Ann Rheum Dis 1996;55:450-4.

14. Parvez N, Carpenter JL. Cardiac tamponade in Still disease: a review of the literature. South Med J 2009:102:832-7.

15. Navaneethan SD, Venkatesh S, Shrivastava R, et al. Recurrent pleural and pericardial effusions due to sarcoidosis. PLoS Med 2005;2:e63.

16. Roy CL, Minor MA, Brookhart MA, et al. Does this patient with a pericardial effusion have cardiac tamponade? JAMA 2007;297:1810-18.

17. Castier M, Albuquerque N, Menezes M, et al. Cardiac tamponade in systemic lupus erythematosus. report of four cases. Arq Bras Cardiol 2000:75:446-8.

18. Hunder GC, Mullen BJ, McDuffie FC. Complement in pericardial fluid of lupus erythematosus. Ann Intern Med 1974;80:453-8.

This pdf has been created automatically from the final edited text and images.

Copyright 2012 BMJ Publishing Group. All rights reserved. For permission to reuse any of this content visit http://group.bmj.com/group/rights-licensing/permissions.

BMJ Case Report Fellows may re-use this article for personal use and teaching without any further permission.

Please cite this article as follows (you will need to access the article online to obtain the date of publication).

Carrion DM, Carrion AF. Cardiac tamponade as an initial manifestation of systemic lupus erythematosus. BMJ Case Reports 2012;10.1136/bcr-03-2012-6126, Published XXX

Become a Fellow of BMJ Case Reports today and you can:

- Submit as many cases as you like

- Enjoy fast sympathetic peer review and rapid publication of accepted articles

- Access all the published articles

- Re-use any of the published material for personal use and teaching without further permission

For information on Institutional Fellowships contact consortiasales@bmjgroup.com

Visit casereports.bmj.com for more articles like this and to become a Fellow 